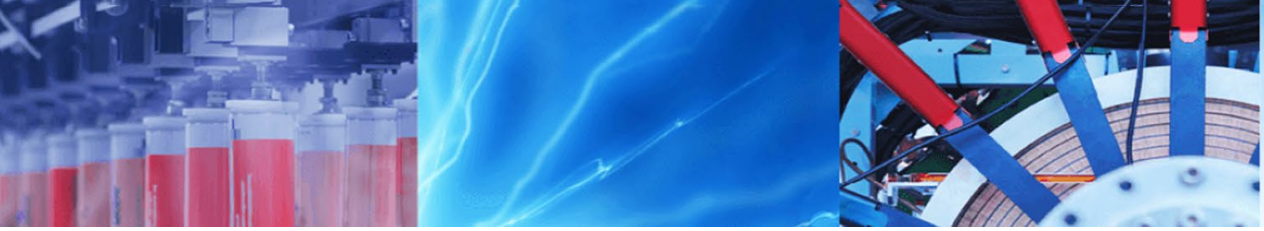

Research Article

\title{
Toxicity of polyelectrolyte-functionalized titania nanoparticles in zebrafish (Danio rerio) embryos
}

\author{
Zeinab H. Arabeyyat ${ }^{1,4} \cdot$ Mohammed J. Al-Awady $^{2,3}$. Gillian M. Greenway ${ }^{3}$. Vesselin N. Paunov ${ }^{3}$. \\ Jeanette M. Rotchell ${ }^{4}(1)$
}

Received: 17 March 2020 / Accepted: 23 June 2020 / Published online: 30 June 2020

(c) The Author(s) 2020 OPEN

\begin{abstract}
We investigated the effects of short-term exposure of bare $\mathrm{TiO}_{2} \mathrm{NPs}$ and polyelectrolyte-coated $\mathrm{TiO}_{2} \mathrm{NPs}_{\mathrm{s}}$ in the $5-25 \mathrm{~nm}$ size range, at relatively high concentrations (of 500 and $1000 \mathrm{mg} / \mathrm{L}$ ) under light or dark conditions, in $D$. rerio embryos. The biological endpoints investigated included embryo viability and mRNA transcript levels of antioxidant and membrane transport genes relative to control embryos. The presence of nanoparticles on the surface of embryos was assessed using TEM. The results confirm an accumulation of $\mathrm{TiO}_{2} \mathrm{NPs}$ on the outer surface (chorion) of the embryo, but not within the embryo. No significant difference in embryo viability was detected following each exposure regime. The expression of antioxidant biomarker, $\mathrm{SOD2}$, was significantly impacted by the type of $\mathrm{TiO}_{2} \mathrm{NP}$, with $\mathrm{TiO}_{2} \mathrm{NPs} / \mathrm{PSS} / \mathrm{PAH}$ coating exposure showing down regulation; the concentration of the nanoparticles, with down regulation at $500 \mathrm{mg} / \mathrm{L}$; and dark/light condition with down regulation in the light. The expression levels of the hypoxia and membrane markers, HIF1 and Pxmp2, were not significantly impacted by any factor. The study indicates that SOD2 mRNA expression levels may be useful in the detection of apparent oxidative stress induced by the titania nanoparticle build up on the embryo chorion surface.
\end{abstract}

Keywords Titania nanoparticles $\cdot$ Zebrafish $\cdot$ Embryos $\cdot$ Oxidative stress

\section{Introduction}

One of the most widely used engineered nanoparticles (NPs) worldwide is nano-sized titanium dioxide NPs $\left(\mathrm{TiO}_{2} \mathrm{NPs}\right)$ that is used for its photocatalytic properties [1]. $\mathrm{TiO}_{2} \mathrm{NPs}$ are used in sunscreens and cosmetic creams [2] for their ability to block UV light [3]. Titania is also used as a pigment in toothpaste [4], in skin treatments [5], and paints, as well as food industry applications $[6,7]$. They have further wide-ranging uses from photosensitizing agents for photodynamic therapy of endobronchial and esophageal cancers [8], as disinfection agents in wastewater treatment [9], as well as in the environmental decontamination of soil, air, and water $[10,11]$.

$\mathrm{TiO}_{2} \mathrm{NPs}$ may be toxic when released into the aquatic environment as they form superoxide and hydroxyl radicals on exposure to sunlight (UV) and oxygen, which could then lead to damage of the cell contents if taken up by organisms [12]. $\mathrm{TiO}_{2} \mathrm{NPs}$ have been categorised into different forms: rutile, anatase, and amorphous [13] whereby the anatase forms are generally found to be more photoactive than rutile $\mathrm{TiO}_{2} \mathrm{NPs}$. Al-Awady et al. [14] reported a

Electronic supplementary material The online version of this article (https://doi.org/10.1007/s42452-020-3137-x) contains supplementary material, which is available to authorized users.

$\triangle$ Jeanette M. Rotchell, J.Rotchell@hull.ac.uk|'Department of Marine Biology, The University of Jordan-Aqaba, P.O. Box: 2595, Aqaba 77110, Jordan. ${ }^{2}$ Department of Genetic Engineering, Faculty of Biotechnology, The Green University of Qasim, Babylon, Iraq. ${ }^{3}$ Department of Chemistry and Biochemistry, University of Hull, Cottingham Road, Hull HU6 7RX, UK. ${ }^{4}$ Department of Biological and Marine Sciences, University of Hull, Cottingham Road, Hull HU6 7RX, UK. 
significant nanotoxicity of $\mathrm{TiO}_{2} \mathrm{NPs}$ against algae and yeast, which depends on the particle surface charge. Nanoparticles with cationic surfaces are generally found to be more toxic than those with anionic surfaces [15]. Several sunscreen products contain anatase $\mathrm{TiO}_{2} \mathrm{NPs}$, which has been found to generate reactive oxygen species (ROS) upon illumination with UV light [16]; this potentially leads to biological damage [17]. Previous studies have shown that $\mathrm{TiO}_{2} \mathrm{NPs}$ (at an exposure level of $5 \mathrm{mg} / \mathrm{L}$ ) induce oxidative stress in the liver of zebrafish [18] and in the brain tissue of rainbow trout (Oncorhynchus mykiss) [19]. In contrast, the potential of $\mathrm{TiO}_{2} \mathrm{NPs}$ to produce oxidative damage to DNA without photoactivation is still unclear [20].

$\mathrm{TiO}_{2} \mathrm{NP}$ toxicity has been shown to be dependent on both particle size and the degree of particle aggregation. Smaller nanoparticles have been found to have higher mobility between biological compartments. For example, the $4 \mathrm{~nm} \mathrm{TiO}{ }_{2} \mathrm{NPs}$ have been observed penetrating into the deeper layer of the epidermis (to the basal cell layer) in hairless mice [21]. In contrast though, $\mathrm{TiO}_{2} \mathrm{NP}$ aggregation, increasing the size factor, has been shown to have a larger effect on cell viability and gene expression of biomarkers focused on stress, inflammation, and cytotoxicity in human acute monocytic leukemia and bronchial epithelial cell lines when compared with smaller aggregates of $166 \mathrm{~nm}$ [22]. Encapsulating the $\mathrm{TiO}_{2} \mathrm{NPs}$ with coating agents (such as inert oxides of silica, alumina, or zirconium) also mediates the ROS associated impacts [23] by reducing or eliminating them. Coatings based on silicon dioxide have also been found to reduce the oxidative activity of $\mathrm{TiO}_{2} \mathrm{NPs}$ on pig skin [24].

Overall, the increased use of $\mathrm{TiO}_{2} \mathrm{NPs}$, and their ultimate release into the environment, suggests an increasing need to evaluate their potential toxicity, including the effect of the nanoparticle coating and size range. In this study, $D$. rerio embryos were used to study the effect of $\mathrm{TiO}_{2} \mathrm{NPs}$ coated with different number of layers of anionic and cationic polyelectrolytes on embryo viability. Selected oxidative stress markers, which are conserved in all vertebrate species, were also measured including superoxide dismutase 2 (SOD2), hypoxia inducible factor 1 (HIF1) and peroxisomal membrane transporter protein (Pxmp2) gene expressions.

\section{Materials and methods}

\subsection{Preparation and characterisation of $\mathrm{TiO}_{2} \mathrm{NPs}$}

Three different batches of $\mathrm{TiO}_{2} \mathrm{NPs}$ were prepared in Milli$\mathrm{Q}$ water: bare titania NPs $\left(\mathrm{TiO}_{2} \mathrm{NPs}\right)$, anionic NPs prepared with poly (sodium 4-styrene sulfonate) sodium salt (PSS) as $\mathrm{TiO}_{2} \mathrm{NPs} / \mathrm{PSS}$, and the cationic NPs prepared with poly (allylamine hydrochloride) (PAH) as $\mathrm{TiO}_{2} \mathrm{NPs} / \mathrm{PSS} / \mathrm{PAH}$. The synthesis of $\mathrm{TiO}_{2} \mathrm{NPs}$ was conducted using the procedure described by Al-Awady et al. [14]—see Fig. 1a. Briefly, $1 \mathrm{M}$
A

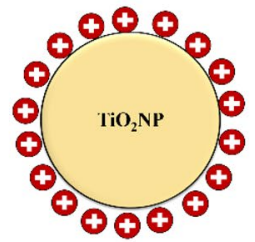

Bare $\mathrm{TiO}_{2} \mathrm{NP}$

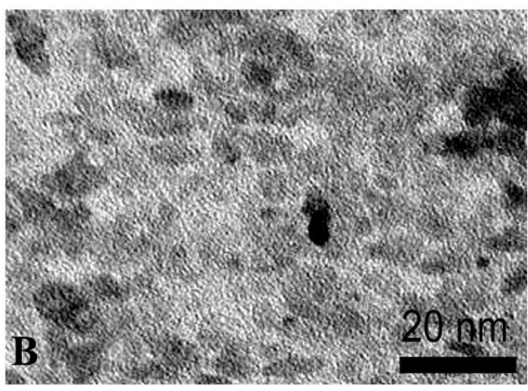

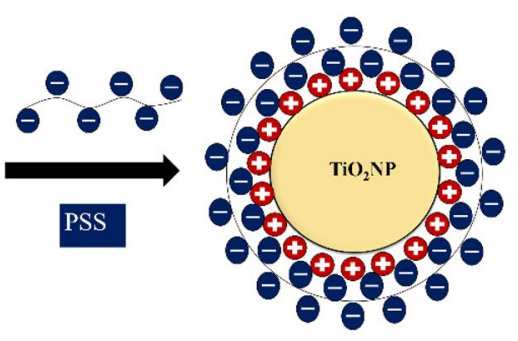

$\mathrm{TiO}_{2} \mathrm{NP} / \mathrm{PSS}$

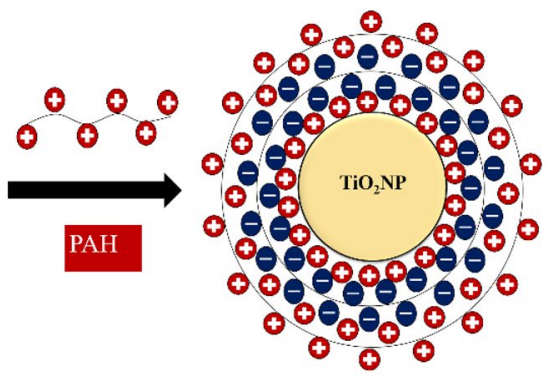

$\mathrm{TiO}_{2}$ NP/PSS/PAH
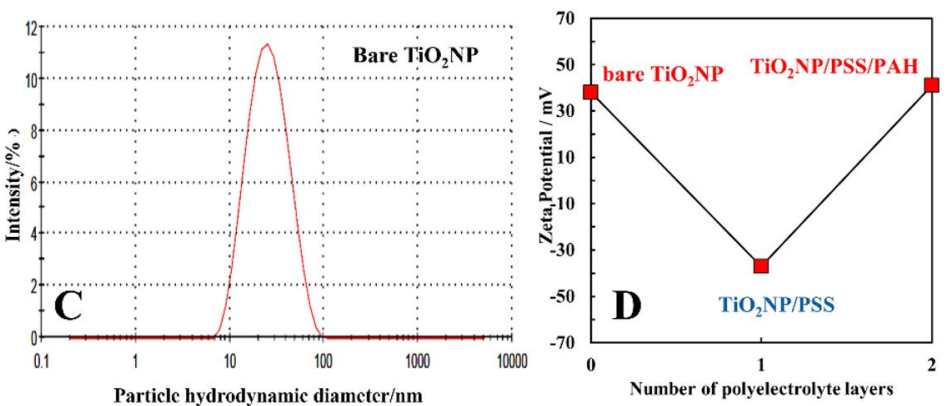

Fig. 1 a Schematic diagram of the coating of the bare $\mathrm{TiO}_{2} \mathrm{NP}$ with polyelectrolytes (PSS and PAH), b TEM image of the titania produced by annealing at $70{ }^{\circ} \mathrm{C}$, c Size distribution of dispersed titanium dioxide NPs synthesised by hydrolysis and condensation of titanium isopropoxide at acidic medium for $20 \mathrm{~h}$ at $70{ }^{\circ} \mathrm{C}$. $\mathbf{d}$ Zetapotential of the bare $\mathrm{TiO}_{2} \mathrm{NP}, \mathrm{TiO}_{2} \mathrm{NP} / \mathrm{PSS}$ and $\mathrm{TiO}_{2} \mathrm{NP} / \mathrm{PSS} / \mathrm{PAH}$ at $\mathrm{pH}$ 5.5

\section{SN Applied Sciences}


$\mathrm{HNO}_{3}$ was added drop-wise to $250 \mathrm{~mL}$ of Milli-Q water to adjust the $\mathrm{pH}$ to 2 followed by dropwise addition of a mixture consisting of $15 \mathrm{~mL}$ aliquot of isopropanol and $5.0 \mathrm{~mL}$ of titanium isopropoxide (TTIP) to the former solution with vigorous stirring, leading to the formation of a white turbid suspension as a result of the hydrolysis of TTIP. The suspension of $\mathrm{Ti}(\mathrm{OH})_{4}$ was heated to $70^{\circ} \mathrm{C}$ for $20 \mathrm{~h}$ to form a yellow-white precipitate of titania that was filtered, washed with ethanol and further dried under vacuum (Gallenkamp vacuum oven) at $100^{\circ} \mathrm{C}$ for $2 \mathrm{~h}$. Aqueous dispersions of $\mathrm{TiO}_{2} \mathrm{NPs}$ was prepared by dispersing $4 \mathrm{mg}$ of the titania sample in $10 \mathrm{~mL}$ aliquots of $20 \mathrm{mM}$ aqueous solution of $\mathrm{NaCl}$ at $\mathrm{pH} 4$ using a digital sonicator (Branson $450,5 \mathrm{~mm}$ tip, $400 \mathrm{~W}$ maximal power) at $40 \%$ of the maximum power for $10 \mathrm{~min}$ at $1 \mathrm{~s}$ ON/ $1 \mathrm{~s}$ OFF pulse time and followed by filtration through a syringe filter of pore size $0.22 \mu \mathrm{m}$. The $\mathrm{TiO}_{2} \mathrm{NPs}$ were characterised in terms of size distribution and zeta potential in aqueous solutions using a Zetasizer Nano ZL (Malvern, U.K.). Transmission electron microscopy (TEM) images of the particle samples were obtained using JEM 2011 (JEOL, Japan) running at $200 \mathrm{kV}$.

\subsection{Layer-by-layer polyelectrolyte-coated $\mathrm{TiO}_{2} \mathrm{NPs}$}

Polyelectrolyte-coated $\mathrm{TiO}_{2} \mathrm{NPs}$ were prepared using titania synthesised and annealed at $100^{\circ} \mathrm{C}$ (anatase). $10 \mathrm{~mL}$ of $1500 \mu \mathrm{g} \mathrm{mL}^{-1} \mathrm{TiO}_{2} \mathrm{NPs}$ dispersion in Milli-Q water was added drop-wise to an equal amount of $10 \mathrm{mg} \mathrm{mL}^{-1}$ of solution of PSS (M.W. $70 \mathrm{kDa}$ ) dissolved in $1 \mathrm{mM} \mathrm{NaCl}$ solution. After shaking for $20 \mathrm{~min}$, the particles were washed three times by centrifugation for $1 \mathrm{~h}$ at $8000 \mathrm{rpm}$ to remove the excess of PSS and were finally re-dispersed in $10 \mathrm{~mL}$ of Milli-Q water. The PSS-coated $\mathrm{TiO}_{2} \mathrm{NPs}$ were then mixed drop-wise with $10 \mathrm{~mL}$ of $10 \mathrm{mg} \mathrm{mL}^{-1} \mathrm{PAH}$ (M.W. $15 \mathrm{kDa}$ ) dissolved in $1 \mathrm{mM} \mathrm{NaCl}$ solution, shaken for $20 \mathrm{~min}$ and centrifuged again three times at $8000 \mathrm{rpm}$ for $1 \mathrm{~h}$ to yield $\mathrm{TiO}_{2} \mathrm{NPs} / \mathrm{PSS} / \mathrm{PAH}$. For further coating with PSS, the latter was mixed drop-wise with $10 \mathrm{~mL}$ of $10 \mathrm{mg} \mathrm{mL}^{-1}$ PSS whilst being sonicated. The mixture was shaken for $20 \mathrm{~min}$, centrifuged and dispersed in Milli-Q water to produce $\mathrm{TiO}_{2} \mathrm{NP} / \mathrm{PSS} / \mathrm{PAH} / \mathrm{PSS}$. Furthermore, PSS and PAH of various molar masses $(10 \mathrm{kDa}$ and $70 \mathrm{kDa}$ for PSS and $15 \mathrm{kDa}$ and $56 \mathrm{kDa}$ for PAH) were used to examine their effect on the size of the coated $\mathrm{TiO}_{2} \mathrm{NPs}$. After each polyelectrolyte coating, the $\mathrm{TiO}_{2} \mathrm{NPs}$ were characterized by the Zetasizer Nano ZL to check their zeta potential and the particle aggregation.

\subsection{Embryo exposure to $\mathrm{TiO}_{2} \mathrm{NPs}$}

Healthy $D$. rerio embryos $(n=10)$ at $0-72 \mathrm{hpf}$, with the chorion intact, were selected and exposed to a treatment dose of test media (bare $\mathrm{TiO}_{2} \mathrm{NPs}$, $\mathrm{TiO}_{2} \mathrm{NPs} / \mathrm{PSS}$, or $\mathrm{TiO}_{2} \mathrm{NPs} / \mathrm{PSS} /$
$\mathrm{PAH}$ ) and incubated for $3 \mathrm{~h}$ in either dark conditions or illuminated with visible light, at particle concentrations of 0,500 or $1000 \mathrm{mg} / \mathrm{L}$ based on published $\mathrm{LC}_{50}$ values to increase the likelihood of observable effects $[25,26]$ rather than environmentally-relevant levels. Healthy $D$. rerio embryos $(n=10)$ were used as a control group in parallel.

\subsection{Embryo viability following exposure to $\mathrm{TiO}_{2} \mathrm{NPs}$}

Embryos (at 48-72 hpf, $\mathrm{n}=5$ ) from each exposure regime (control, bare $\mathrm{TiO}_{2} \mathrm{NPs}$, $\mathrm{TiO}_{2} \mathrm{NPs} / \mathrm{PSS}$, and $\mathrm{TiO}_{2} \mathrm{NPs} / \mathrm{PSS} / \mathrm{PAH}$ ) were isolated after the exposure and washed with commercially supplied (nuclease free) molecular-biology grade water (Fisher Scientific, U.K.) three times, and re-dispersed with $1 \mathrm{~mL}$ molecular grade water and incubated with a drop of $98 \%$ fluorescein diacetate (FDA) (Honeywell Fluka, U.K.) in acetone ( $0.5 \mathrm{mg} / \mathrm{L})$ for $15 \mathrm{~min}$. This assay is based on accumulation of the fluorescent by-product (fluorescein) inside the viable embryos as a result of the hydrolysis of the diffused FDA by intracellular enzymes (esterases). The embryos were then washed again with deionised water and the cell viability examined using an Olympus BX51 fluorescence microscope attached to a DP70 digital camera and FITC fluorescence filter set. Living cells were identified as having taken up FDA and fluorescent green [27].

\subsection{TEM imaging of embryos after exposure to $\mathrm{TiO}_{2} \mathrm{NPs}$}

The morphology of $D$. rerio embryos $(n=5)$ after a $3 \mathrm{~h}$ incubation with 0,500 or $1000 \mathrm{mg} / \mathrm{L}$ of bare $\mathrm{TiO}_{2} \mathrm{NPs}^{\mathrm{TiO}}{ }_{2} \mathrm{NPs} /$ $\mathrm{PSS}$, or $\mathrm{TiO}_{2} \mathrm{NPs} / \mathrm{PSS} / \mathrm{PAH}$ was examined with TEM using the following protocol. The embryos were washed with deionised water and fixed in $2.5 \%$ glutaraldehyde $(0.5 \mathrm{ml}$ $25 \%$ glutaraldehyde stock solution, $4.5 \mathrm{ml} 0.1 \mathrm{M}$ cacodylate buffer and glucose ( $20 \mathrm{~mL} 0.2 \mathrm{M}$ cacodylate stock, $10 \mathrm{~mL}$ Milli-Q water, $0.216 \mathrm{~g}$ glucose, $\mathrm{pH} 7.3$, and final volume made up to $40 \mathrm{~mL}$ ) for $1 \mathrm{~h}$ at room temperature. Next, cacodylate buffer was removed and embryos were fixed by $1 \%$ osmium tetra-oxide in cacodylate buffer $(2.5 \mathrm{~mL} 2 \%$ Osmium tetroxide, $2.5 \mathrm{~mL} 0.1 \mathrm{M}$ cacodylate buffer and glucose $0.03 \mathrm{M}$ ) at $4{ }^{\circ} \mathrm{C}$ overnight. After the cacodylate buffer was removed, embryos were stained for $30 \mathrm{~min}$ with $1 \%$ uranyl acetate $(2 \mathrm{ml} 2.5 \%$ uranyl acetate stock, final volume $3 \mathrm{~mL}$ ) and washed with solutions of ethanol of increasing concentration (30\%,50\%, and $70 \%$ overnight). The embryos were washed again the next day with ethanol solutions of $90 \%$ and $100 \%$. After standard dehydration, the embryos were embedded in fresh epoxy/araldite at $60^{\circ} \mathrm{C}$ for $48 \mathrm{~h}$. The embedded embryo samples were removed from the oven and allowed to stand at room temperature for $48 \mathrm{~h}$, then sectioned using an ultramicrotome. 
The Oxford Instruments INCA Energy Dispersive Spectroscopy (EDS) was attached to the TEM and run at $120 \mathrm{kV}$ to identify and semi-quantitatively characterize the $\mathrm{TiO}_{2} \mathrm{NPs}$ on the surface, or within, of the $D$. rerio embryo samples. The sectioned samples were imaged using a JEOL 2010 TEM (Japan) operating at $80 \mathrm{kV}$ and images were captured (from one randomly selected embryo per treatment group) with a Gatan Ultrascan 4000 digital camera (Gatan, Pleasanton, U.S.A.) and the corresponding software for imaging was the Digital Micrograph.

\subsection{Target gene isolation and characterization}

Total RNA was extracted from pooled samples of embryos (0-72 hpf with chorion intact, $\mathrm{n}=10$ ) from each treatment group, using the manufacturer's protocol (Roche Diagnostics Ltd., Burgess Hill, U.K.). The embryo pooled sample exposures consisted of bare $\mathrm{TiO}_{2} \mathrm{NPs}_{2} \mathrm{TiO}_{2} \mathrm{NPs} / \mathrm{PSS}$, or $\mathrm{TiO}_{2} \mathrm{NPs} / \mathrm{PSS} / \mathrm{PAH}$ at 500 or $1000 \mathrm{mg} / \mathrm{L}$ particle concentration for $3 \mathrm{~h}$ exposure duration, in dark or illuminated with visible light as well as the corresponding control treatment group $(n=10)$. To assess the integrity of total RNA, samples were analysed on a denaturing agarose gel stained with ethidium bromide (Life Technologies, Paisley, U.K.). $100 \mathrm{ng}$ of pooled RNA was used to generate CDNA using SuperScript VILO cDNA Synthesis reagents and protocol (Life Technologies, Paisley, U.K.) with $14 \mu \mathrm{L}$ ( 100 ng) of total RNA. In a $0.2 \mathrm{~mL}$ tube, the following reagents were added: $4 \mu \mathrm{L}$ of $5 x$ VILO Reaction Mix (includes random primers, $\mathrm{MgCl}_{2}$, and dNTPs in a buffer formulation) $2 \mu \mathrm{L}$ of 10x Superscript enzyme mix. Each reaction was incubated at $25^{\circ} \mathrm{C}$ for $10 \mathrm{~min}$, and then $60 \mathrm{~min}$ at $42^{\circ} \mathrm{C}$ followed by $5 \mathrm{~min}$ at $85^{\circ} \mathrm{C}$ and a holding step at $4{ }^{\circ} \mathrm{C}$. To degrade any remaining $\mathrm{RNA}$, the following reagents were added: $0.5 \mu \mathrm{L}$ (5 units) of RNase $\mathrm{H}$ (supplied in $100 \mathrm{mM} \mathrm{KCl}, 20 \mathrm{mM}$ Tris- $\mathrm{HCl}$ (pH 7.5), $10 \mathrm{mM} \mathrm{MgCl}$, $0.1 \mathrm{mM}$ EDTA, $0.1 \mathrm{mM}$ dithiothreitol and $50 \%$ glycerol) and $2 \mu \mathrm{L}$ of $10 \times$ RNase $\mathrm{H}$ Reaction Buffer (includes $75 \mathrm{mM} \mathrm{KCl}, 50 \mathrm{mM}$ Tris- $\mathrm{HCl}$, $3 \mathrm{mM} \mathrm{MgCl}_{2}, 10 \mathrm{mM} \mathrm{MgCl}_{2}$ in pH 8.3 at $25^{\circ} \mathrm{C}$ ). All reagents were mixed, incubated at $37^{\circ} \mathrm{C}$ for $45 \mathrm{~min}$ and then stored at $-20^{\circ} \mathrm{C}$.

For the generation of SOD2, HIF1, and Pxmp2 PCR products, $1 \mu \mathrm{L}$ of cDNA was combined with $0.5 \mu \mathrm{l}$ of $10 \mathrm{mM}$ dNTPs, $5 \mu \mathrm{L}$ amplification buffer, $0.5 \mu \mathrm{L}$ of $0.5-4.5 \mathrm{mM} \mathrm{MgCl}_{2}$, $0.5 \mu \mathrm{L}$ of $1.5 \mu \mathrm{M}$ for each sense and antisense primers (Table S-1) and $0.25 \mu \mathrm{L}$ (1.25 units) of Herculase II fusion DNA polymerase (Agilent Technologies, Wokingham, U.K.) for a total reaction volume of $25 \mu \mathrm{L}$. Elongation factor 1 (EF), $18 \mathrm{~S} r R N A$ (18S) and $\beta$ tubulin were evaluated as potential reference genes. Amplifications were carried out using the TC-4000 Thermal Cycler (Techne, Staffordshire, U.K.) equipped with a heated lid. All reactions were initially denatured at $94^{\circ} \mathrm{C}$ for $30 \mathrm{~s}$ then cycled 35 times with $30 \mathrm{~s}$ at $94^{\circ} \mathrm{C}$ denaturation, $30 \mathrm{~s}$ at $50 / 55 / 60^{\circ} \mathrm{C}$ annealing and $30 \mathrm{~s}$ at $72^{\circ} \mathrm{C}$ for the elongation step. A final extension step of $2 \mathrm{~min}$ at $72^{\circ} \mathrm{C}$ was conducted. The PCR fragments were sequenced commercially by Macrogen (Amsterdam, Netherlands). Identities of PCR fragments were verified using a blastn search on the NCBI database (http://blast.ncbi.nlm.nih.gov/Blast.cgi), and aligned using a multiple sequence alignment program, Clustal Omega (http://www.ebi.ac.uk/Tools/msa/clustalo/) to determine the correct isoform.

\subsection{Quantitative qPCR analysis of mRNA expression}

The qPCRs analyses for each pool of embryo cDNAs from each treatment group $(n=10)$ were carried out using $20 \mu \mathrm{L}$ reaction volumes consisting of $10 \mu \mathrm{L}$ of SYBR Green Master Mix (Roche, U.K.), $7 \mu \mathrm{L}$ of sterilised water, $1 \mu \mathrm{L}$ of the cDNA template, and $2 \mu \mathrm{L}$ of optimised primer concentration (EF, HIF1: 200 nM; 18S, Pxmp2: 300 nM, SOD2: 400 nM). Two reference genes ( $E F$ and $18 S$ ) were determined as the most stable across treatment groups using geNorm software. Amplifications were carried out using a CFX96 Real-time PCR system, C1000 Thermal Cycler (Bio-Rad, Hemel Hempstead, U.K.), in triplicate and with negative controls. Reactions were started with denaturation at $50^{\circ} \mathrm{C}$ for $2 \mathrm{~min}, 95^{\circ} \mathrm{C}$ for $10 \mathrm{~min}$, followed by a three-step protocol of 40 cycles of denaturation at $95^{\circ} \mathrm{C}$ for $10 \mathrm{~s}$, annealing at $60^{\circ} \mathrm{C}$ for $1 \mathrm{~min}$, then $72^{\circ} \mathrm{C}$ for $1 \mathrm{~min}$. At the end, a melting/dissociation curve was conducted. A relative quantification method was used to determine changes in mRNA transcript levels of the targeted genes in the treatment group compared to untreated control samples using the geometric mean of the reference genes for normalization and the $\Delta \Delta C \mathrm{C}$ method [28].

\subsection{Statistical analysis}

Each target gene was tested individually for significant differences among the controls and each treatment group. All data were tested for homogeneity of variances using Levene's test in SPSS. A non-parametric test (Scheirer-RayHare) was used to assess the effect of anatase $\mathrm{TiO}_{2} \mathrm{NPs}$ coating type (factor 1 ), $\mathrm{TiO}_{2} \mathrm{NP}$ concentration (factor 2 ) and the exposure condition (factor 3 ) and to determine the interactions among them. Significance for relative gene expression, between $\mathrm{TiO}_{2} \mathrm{NP}$ of different coatings, concentrations, or conditions was also tested individually using the Kruskal-Wallis non-parametric test. Differences were considered significant at $P<0.05$. 


\section{Results}

\subsection{Characterization of the $\mathrm{TiO}_{2} \mathrm{NPs}$ size distribution and zeta potential}

Aqueous dispersions of the titania samples were synthesized at different annealing temperatures and prepared by sonication as described by Al-Awady et al. [14]. Figure 1a illustrates schematically the process of coating of the bare $\mathrm{TiO}_{2} \mathrm{NPs}$ with consecutive layers of PSS and PAH respectively. Figure $1 \mathrm{~b}$ shows a typical TEM image of the bare $\mathrm{TiO}_{2} \mathrm{NPs}$ used in these experiments. The titania produced was characterized as clusters of smaller crystallites of $5 \mathrm{~nm}$ domain size in solid state (Fig. 1b). Upon dispersing in Milli-Q water at $\mathrm{pH} 5.5, \mathrm{TiO}_{2} \mathrm{NPs}$ of an average diameter $25 \mathrm{~nm}$ (Fig. 1c) were produced. The zeta potential of the anatase $\mathrm{TiO}_{2} \mathrm{NPs}$ in an aqueous solution decreased gradually from positive at low $\mathrm{pH}$ to negative at high $\mathrm{pH}$ with an isoelectric point at approximately 6.8 (see Fig. 1d).

\section{2 $\mathrm{TiO}_{2} \mathrm{NP}$ uptake and impact on $\mathrm{D}$. rerio embryo viability}

Embryos displayed no significant impact on viability (Fig. 2) when exposed to all the $\mathrm{TiO}_{2} \mathrm{NPs}$ types (bare $\mathrm{TiO}_{2} \mathrm{NPs}_{1} \mathrm{TiO}_{2} \mathrm{NPs} / \mathrm{PSS}$, or $\mathrm{TiO}_{2} \mathrm{NPs} / \mathrm{PSS} / \mathrm{PAH}$ ) at each exposure level $(0,500$ and $1000 \mathrm{mg} / \mathrm{L})$, in both dark and visible

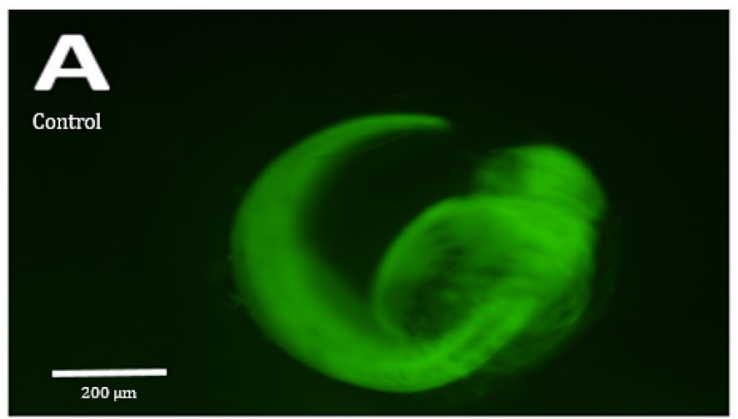

\section{B}

Bare $\mathrm{TiO}_{2} \mathrm{NPs}$
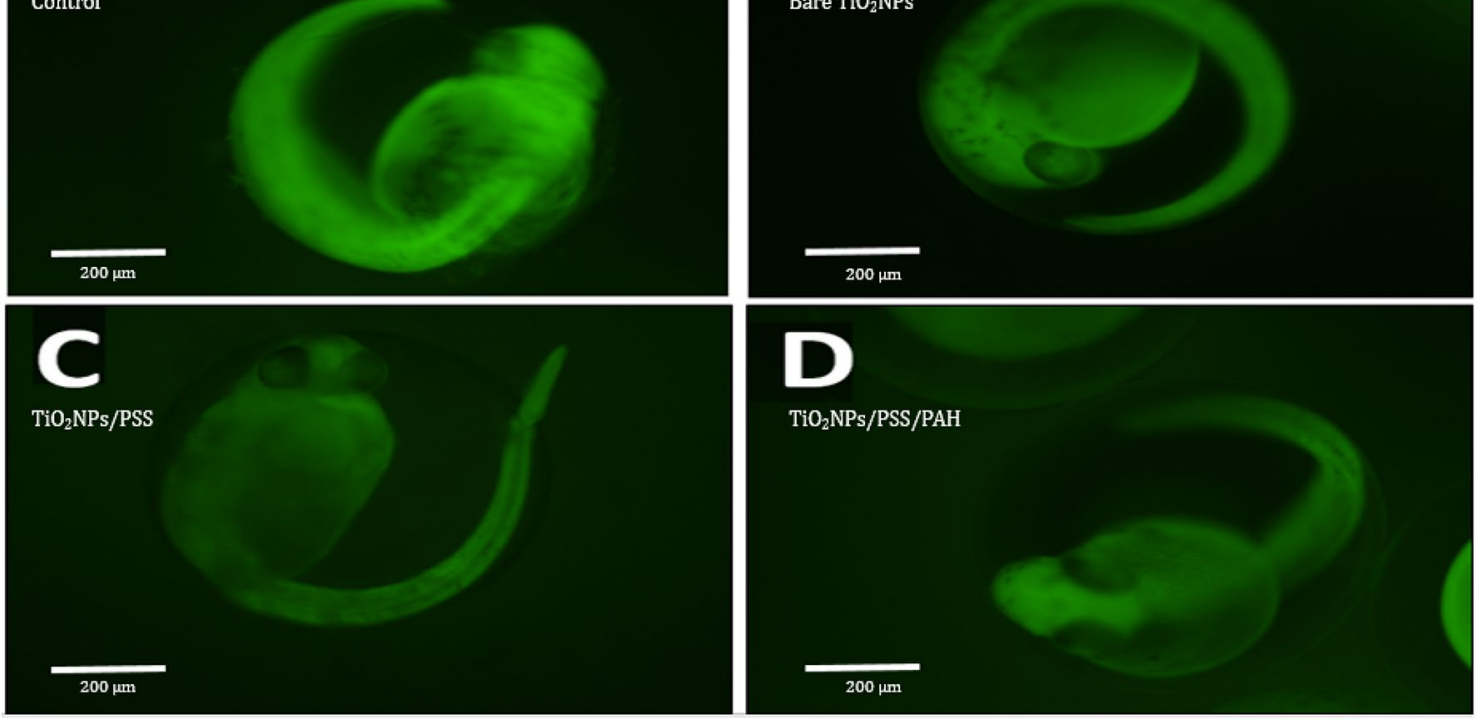

Fig. 2 FDA live/dead assay applied to $D$. rerio embryos (at 48-72 hpf, $\mathrm{n}=5$ ) exposed to different types of $\mathrm{TiO}_{2} \mathrm{NPs}$ samples at total concentrations of $1000 \mathrm{mg} / \mathrm{L}$ for each media and under visible light light conditions. D. rerio embryos from each of the treatment group were examined using EDS attached to TEM (Fig. 3, Table 1). EDS spectra confirmed the presence of $\mathrm{TiO}_{2} \mathrm{NPs}$ on the outer surface (chorion) of $D$. rerio embryo incubated with $500 \mathrm{mg} / \mathrm{L}$ of $\mathrm{TiO}_{2} \mathrm{NPs} / \mathrm{PSS}$ under both dark and visible light conditions (Fig. 3 b, c). In the samples examined using TEM, no TiO ${ }_{2} \mathrm{NPs}$ were detected inside of the embryos for any treatment or on the embryo outer surface (chorion) in the control group (Fig. 3a) or after incubation with $500 \mathrm{mg} / \mathrm{L}$ of $\mathrm{TiO}_{2} \mathrm{NPs} / \mathrm{PSS} / \mathrm{PAH}$ under both dark and visible light conditions (Fig. $3 \mathrm{~d}$, e). $\mathrm{TiO}_{2} \mathrm{NPs}$ were however detected on the outer surface (chorion) of embryos incubated with $1000 \mathrm{mg} / \mathrm{L} \mathrm{TiO}{ }_{2} \mathrm{NPs} / \mathrm{PSS} / \mathrm{PAH}$ incubated under dark conditions (Fig. 3f). No data was available (due to human error) for embryos incubated with $1000 \mathrm{mg} / \mathrm{L}$ $\mathrm{TiO}_{2} \mathrm{NPs} / \mathrm{PSS} / \mathrm{PAH}$ incubated under light conditions.

\section{3 qPCR analysis of target gene expression in $D$. rerio embryos following exposure to $\mathrm{TiO}_{2} \mathrm{NPs}$}

The expression levels of SOD2, HIF1, and Pxmp2 mRNA were analysed in control embryos and embryos pooled from each treatment group $(n=10)$ of $\mathrm{TiO}_{2} \mathrm{NPs}$ with concentrations of 0,500 and $1000 \mathrm{mg} / \mathrm{L}$ in dark and visible light conditions using the optimised qPCR method. Firstly, an overall statistical analysis using the ScheirerRay-Hare test (Table 2) showed that for the nanoparticles the $\mathrm{TiO}_{2} \mathrm{NP}$ type, concentration, condition, the conditions: a Control, b bare $\mathrm{TiO}_{2} \mathrm{NPs}$, c $\mathrm{TiO}_{2} \mathrm{NPs} / \mathrm{PSS}$, d $\mathrm{TiO}_{2} \mathrm{NPs} /$ $\mathrm{PSS} / \mathrm{PAH}$. Scale bars are $200 \mu \mathrm{m}(\mathbf{a}-\mathbf{d})$. The fluorescence signal indicates that the embryos are still viable after exposure 


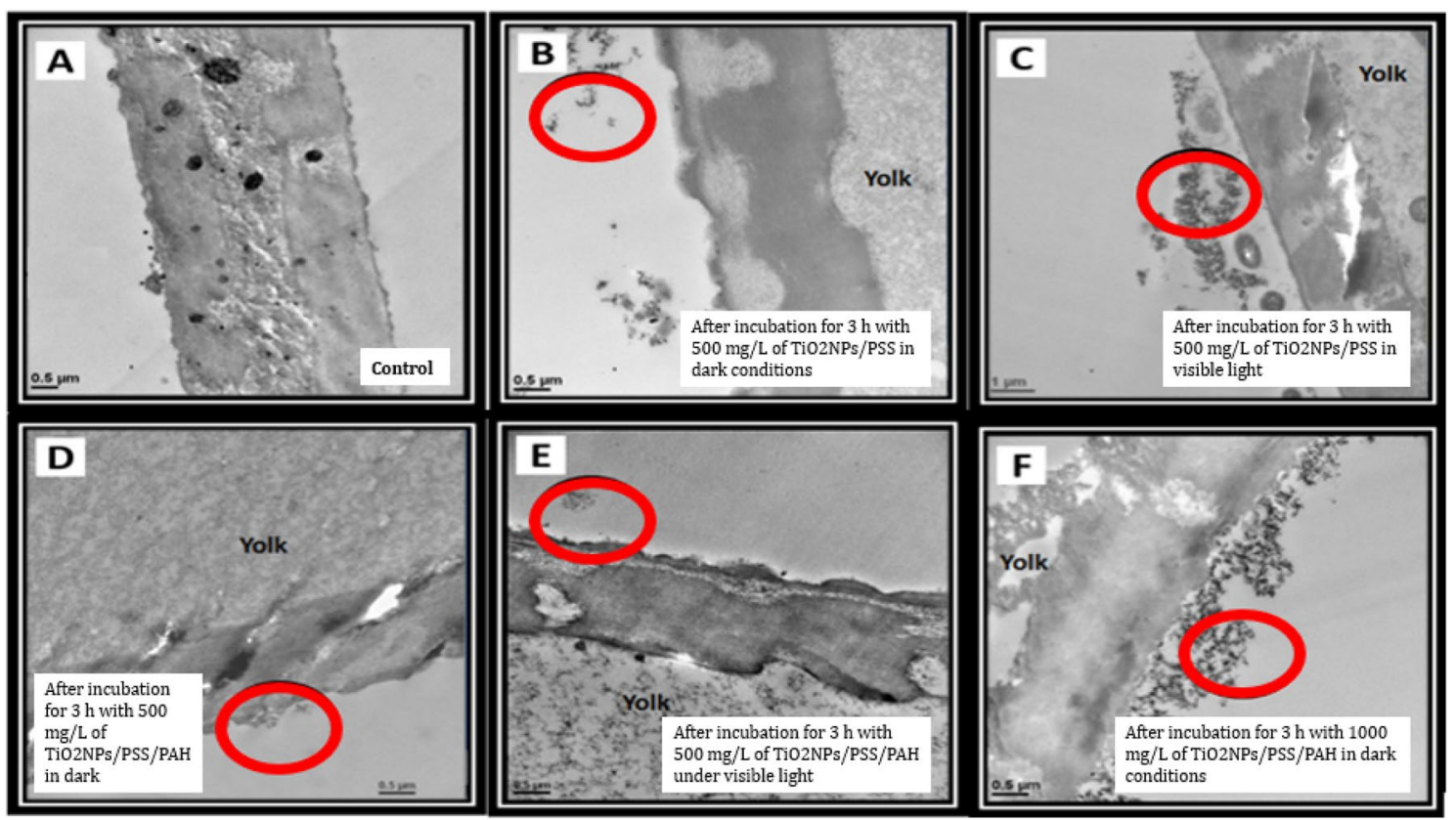

Fig. 3 TEM images of $D$. rerio embryo outer surface (chorion) in a control treatment, b after incubation for $3 \mathrm{~h}$ with $500 \mathrm{mg} / \mathrm{L}$ of $\mathrm{TiO}_{2} \mathrm{NPs} / \mathrm{PSS}$ in dark conditions, c after incubation for $3 \mathrm{~h}$ with $500 \mathrm{mg} / \mathrm{L}$ of $\mathrm{TiO}_{2} \mathrm{NPs} / \mathrm{PSS}$ in visible light, $\mathbf{d}$ after incubation for $3 \mathrm{~h}$ with $500 \mathrm{mg} / \mathrm{L}$ of $\mathrm{TiO}_{2} \mathrm{NPs} / \mathrm{PSS} / \mathrm{PAH}$ in dark, e after incubation for
$3 \mathrm{~h}$ with $500 \mathrm{mg} / \mathrm{L}$ of $\mathrm{TiO}_{2} \mathrm{NPs} / \mathrm{PSS} / \mathrm{PAH}$ under visible light, $\mathbf{f}$ after incubation for $3 \mathrm{~h}$ with $1000 \mathrm{mg} / \mathrm{L}$ of $\mathrm{TiO}_{2} \mathrm{NPs} / \mathrm{PSS} / \mathrm{PAH}$ in dark conditions. The circles represent the areas used for the EDS spectrum analysis
Table 1 Trace amounts of titania detected on the surface (chorion) of embryo samples $(n=5)$ exposed to different coated titania treatments using EDS-TEM analysis

\begin{tabular}{lll}
\hline Embryo treatment group & Condition & $\begin{array}{l}\text { Titania (\% of } \\
\text { elemental } \\
\text { weight) }\end{array}$ \\
\hline Control & Light & 0 \\
$500 \mathrm{mg} / \mathrm{L}$ anionic $\mathrm{TiO}_{2} \mathrm{NPs} / \mathrm{PSS}$ & Dark & 2.99 \\
$500 \mathrm{mg} / \mathrm{L}$ anionic $\mathrm{TiO}_{2} \mathrm{NPs} / \mathrm{PSS}$ & Light & 15.2 \\
$500 \mathrm{mg} / \mathrm{L}$ cationic $\mathrm{TiO}_{2} \mathrm{NPs} / \mathrm{PSS} / \mathrm{PAH}$ & Dark & 0 \\
$500 \mathrm{mg} / \mathrm{L}$ cationic $\mathrm{TiO}_{2} \mathrm{NPs} / \mathrm{PSS} / \mathrm{PAH}$ & Light & 0 \\
$1000 \mathrm{mg} / \mathrm{L}$ cationic $\mathrm{TiO}_{2} \mathrm{NPs} / \mathrm{PSS} / \mathrm{PAH}$ & Dark & 24.85 \\
\hline
\end{tabular}

Table 2 Summary of the statistical analyses on the effect of $\mathrm{TiO}_{2} \mathrm{NPs}$, coated with different anionic (PSS) and cationic (PAH) polyelectrolytes, on the mRNA expression level of SOD2, HIF1 and interaction between the types and concentration; and the interaction between the concentration and condition all significantly affected the relative gene expression levels of SOD2 mRNA (Table 2). The expression level of HIF1 was only affected by the condition (light or dark) used in the experiment (Table 2). Pxmp2 mRNA expression level was not significantly impacted by any of the types of $\mathrm{TiO}_{2} \mathrm{NPs}$, concentration, nor the exposure regime (Table 2 ).

A Kruskal-Wallis test highlighted further significance within the dataset as follows. Significant difference in SOD2 expression level was detected as a result of $\mathrm{TiO}_{2} \mathrm{NP}$ type,

\begin{tabular}{|c|c|c|c|c|c|c|c|c|c|c|}
\hline \multirow[t]{2}{*}{ Gene } & \multicolumn{7}{|c|}{ Scheirer-Ray-Hare test } & \multicolumn{3}{|c|}{ Kruskal-Wallis test } \\
\hline & Types & Conc & Cond & $\operatorname{Int}^{1}$ & $\operatorname{lnt}^{2}$ & $\operatorname{lnt}^{3}$ & $\operatorname{lnt}^{4}$ & Types & Conc & Cond \\
\hline SOD2 & $P<0.05$ & $P<0.05$ & $P<0.05$ & $P<0.05$ & ns & $P<0.05$ & ns & $P<0.05$ & ns & $P<0.05$ \\
\hline HIF1 & ns & ns & $P<0.05$ & ns & ns & ns & ns & ns & ns & ns \\
\hline Pxmp2 & ns & ns & ns & ns & ns & ns & ns & ns & ns & $P<0.05$ \\
\hline
\end{tabular}

Effect of concentration (Conc), Exposure condition (Cond), ${ }^{1}$ Interaction between types of $\mathrm{TiO}_{2} \mathrm{NPs}_{\text {and }}$ concentration (Int ${ }^{1}$ ), ${ }^{2}$ Interaction between types of $\mathrm{TiO}_{2} \mathrm{NPs}$ and exposure condition $\left(\mathrm{Int}^{2}\right),{ }^{3}$ Interaction between concentration and exposure condition (Int $\left.{ }^{3}\right),{ }^{4}$ Interaction between types of $\mathrm{TiO}_{2} \mathrm{NPs}$, concentration, and exposure condition $\left(\operatorname{Int}^{4}\right)$, ns not significant 

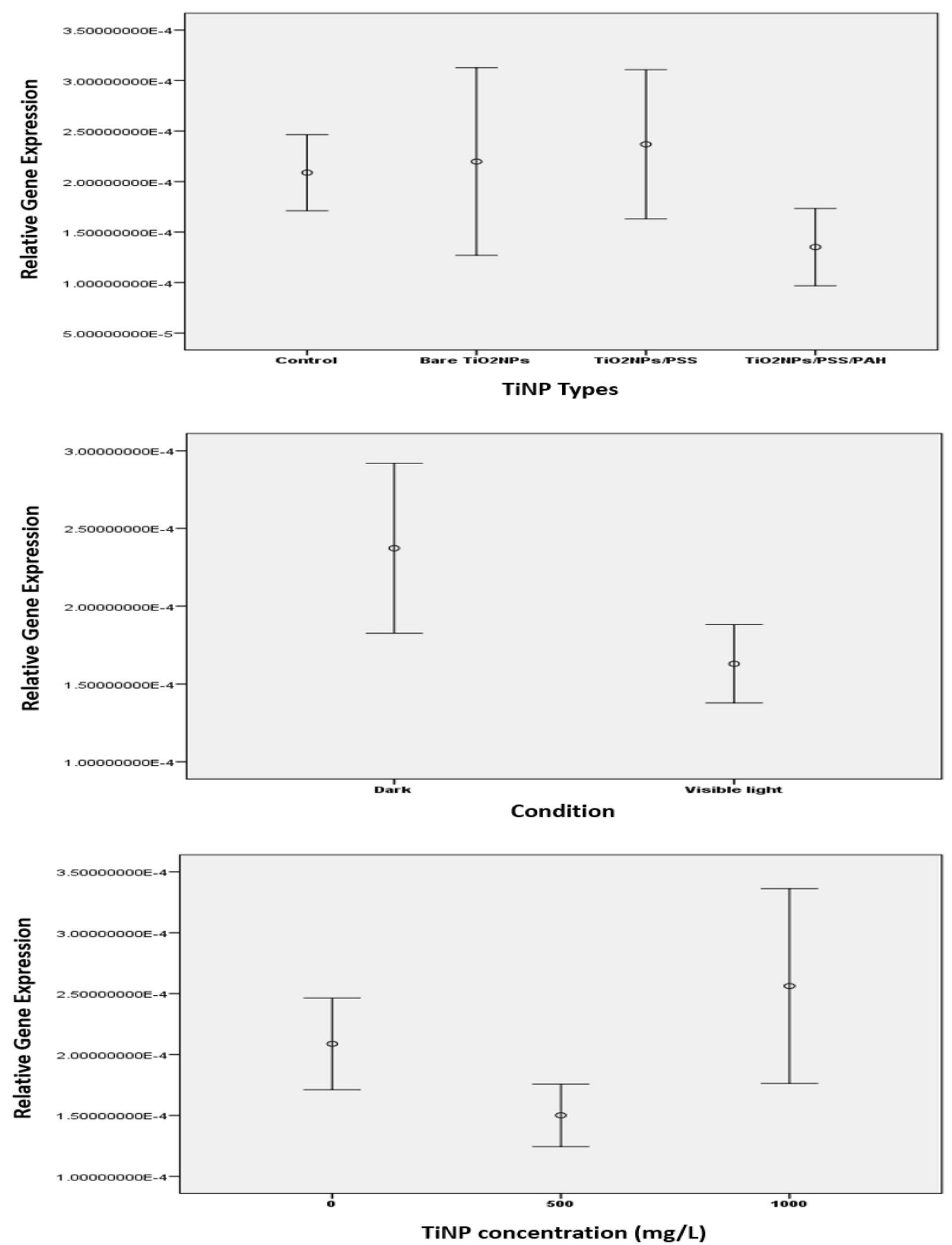

Fig. 4 SOD2 mRNA shows significant expression levels differences based on titania type. Relative SOD2 mRNA expression level in pooled embryo samples (0-72 hpf, $\mathrm{n}=10)$ are shown

concentration, and condition (Fig. 4). HIF1 expression was significantly affected by condition (Fig. 5). Pxmp2 expression was not affected by any condition (Fig. 6). Separate
Kruskal-Wallis tests (Table 2) for one-way analysis of the individual data between $\mathrm{TiO}_{2} \mathrm{NPs}$ types, concentration, and condition, revealed that SOD2 mRNA expression was 

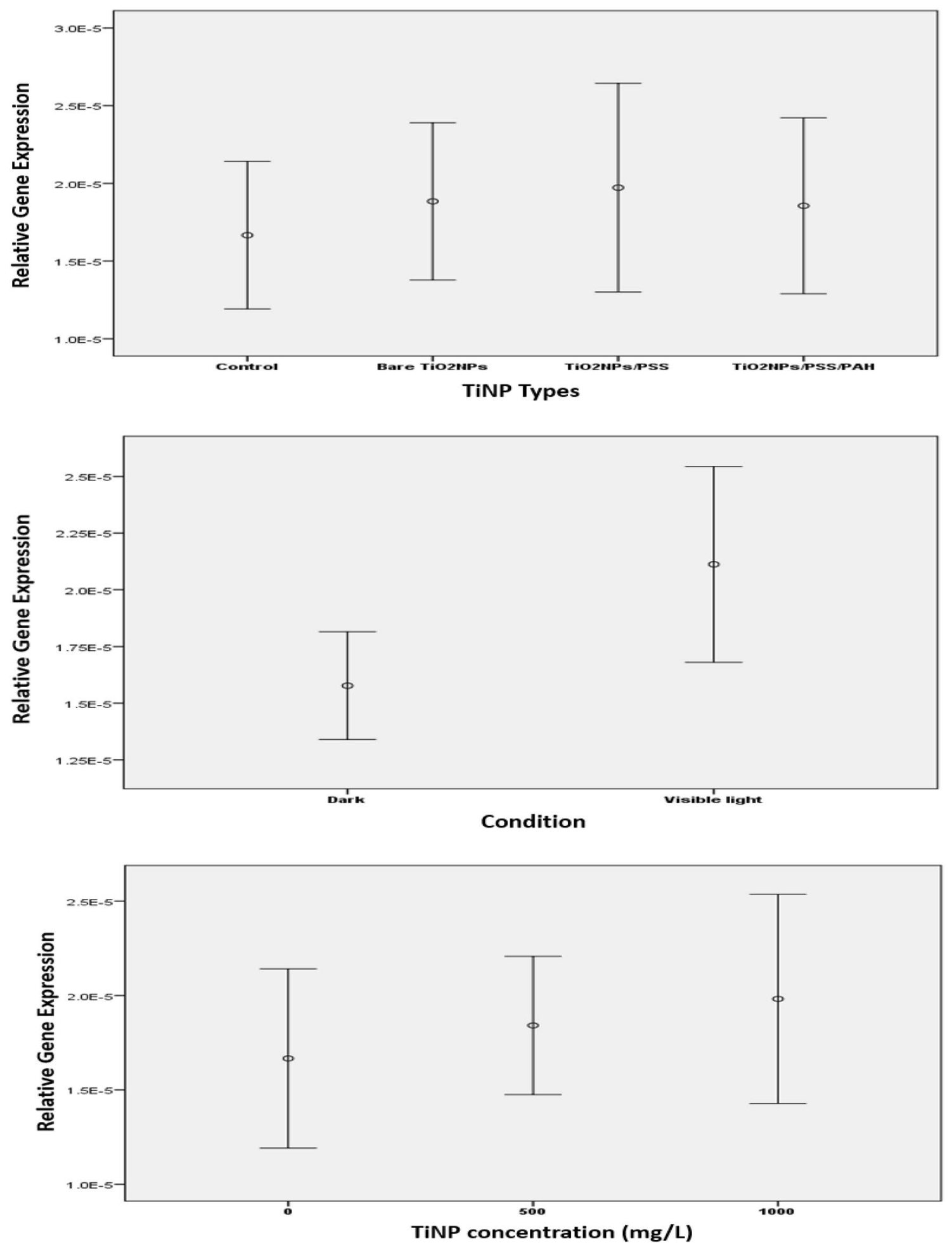

Fig. 5 HIF1 mRNA shows no significant expression levels differences based on titania type, concentration or condition. Relative HIF1 mRNA expression level in pooled embryo samples (0-72 hpf, $\mathrm{n}=10$ ) following exposure to $\mathrm{TiO}_{2} \mathrm{NPs}$ with various coatings, concentrations and dark/light conditions 

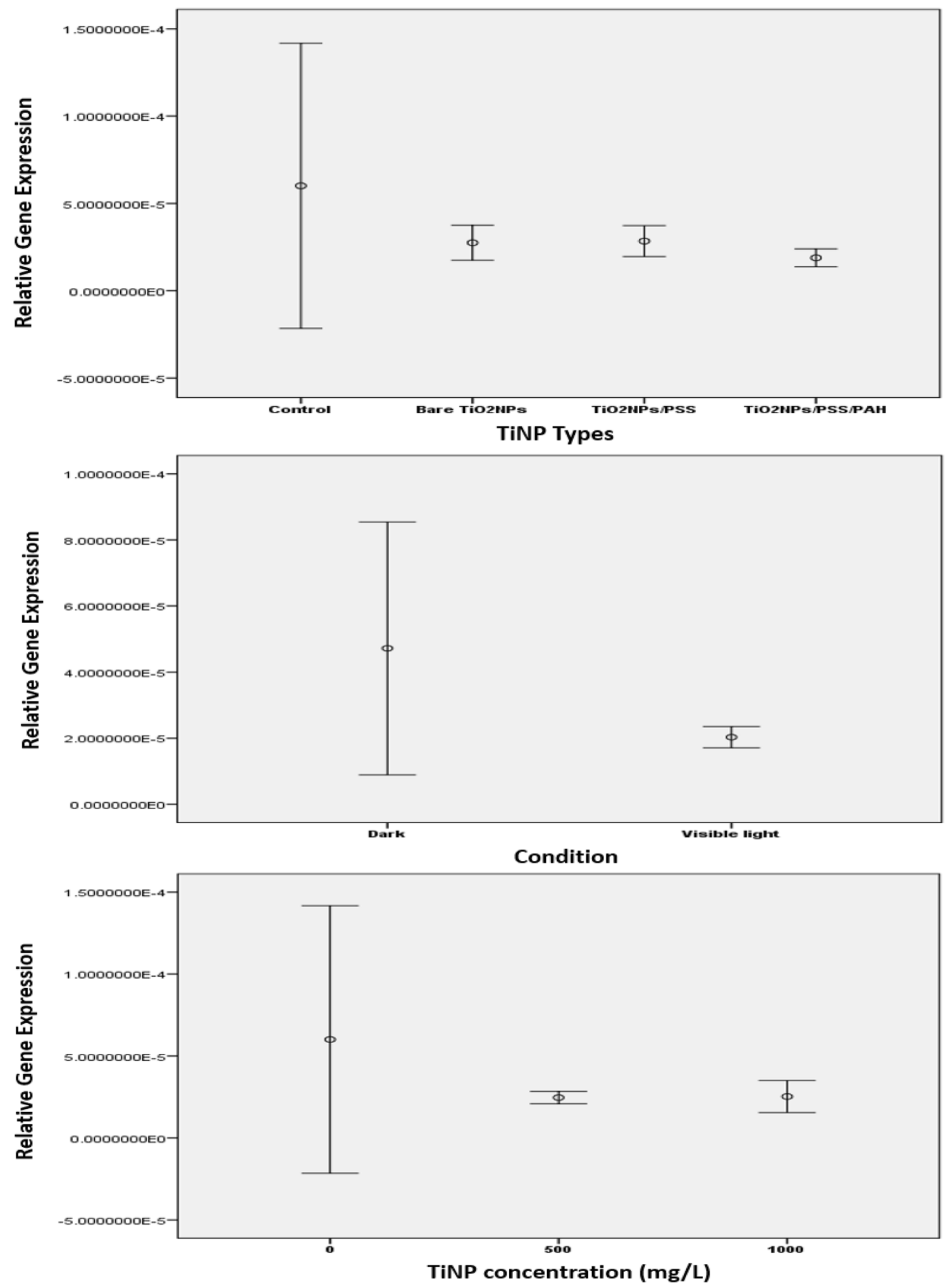

Fig. 6 Pxmp2 mRNA shows no significant expression levels differences based on titania type, concentration or condition. Relative Pxmp2 mRNA expression level in pooled embryo samples (0-72 hpf, $\mathrm{n}=10$ ) following exposure to $\mathrm{TiO}_{2} \mathrm{NPs}$ with various coatings, concentrations and dark/light conditions 
significantly affected by both types and condition. HIF1 mRNA didn't show any significant differences in expression by any factors, and Pxmp2 mRNA expression shows significant difference only by condition as a result of light/ dark effect.

\section{Discussion}

From this study, using two relatively high exposure levels of uncoated and coated titania NPs (500 and $1000 \mathrm{mg} / \mathrm{L}$ ), it is evident that overall embryo viability is not affected (Fig. 2), even though titania can be detected on the surface (chorion) of embryos (Fig. 3b, C, f), and significant changes in oxidative stress gene expression, particularly $S O D 2$ was detected in selected exposure treatment groups (Fig. 4). On the other hand, the markers adopted for hypoxia (HIF1, Fig. 5) and membrane function (Pxmp2, Fig. 6), suggest that such high exposure levels of these NPs are not having a significant impact on these specific endpoints under this exposure regime.

In terms of NPs availability and uptake, the anatase NPs employed in this study had an average diameter of $25 \mathrm{~nm}$ with a range of different coatings. Their impact on viability and their apparent absence within the embryos analysed, would suggest that they are not crossing the embryo and/or causing mortality under the exposure conditions used. This is consistent with studies using eggs and adult zebrafish that reported an $\mathrm{LC}_{50}$ value of $>1600 \mathrm{mg} / \mathrm{L}$ for uncoated $\left(<100 \mathrm{~nm}\right.$ sized) $\mathrm{TiO}_{2} \mathrm{NPs}$ after a $48 \mathrm{~h}$ exposure period [29]. Studies using significantly longer exposure times (of 23 days) have shown decreased survival of $D$. rerio embryos exposed to $\mathrm{TiO}_{2} \mathrm{NPs}$ at lower concentrations from $10 \mu \mathrm{g} / \mathrm{L}$ to $10 \mathrm{mg} / \mathrm{L}$ [30]. Adding UV light has also been shown to increase mortality, in larvae rather than embryos, at concentrations of $1-100 \mathrm{mg} / \mathrm{L}[31,32]$. The $D$. rerio embryo is $\sim 1.5 \mathrm{~mm}$ thick [33], is surrounded by a protective chorion, which, at $72 \mathrm{hpf}$, is considered open to the passage of materials through pores or via passive transport [34], yet these results suggest that no nanoparticle transfer across the chorion has occurred.

Two coatings were compared with each other in terms of relative uptake and toxicity. The $\mathrm{TiO}_{2} \mathrm{NPs} / \mathrm{PSS} / \mathrm{PAH}$ used are cationic and UV-photoactive, similarly to the uncoated $\mathrm{TiO}_{2} \mathrm{NPs}$, i.e. their positive charge is anticipated to promote adhesion on the embryo surface. However these were only identified on the surface of the embryos exposed to the higher $1000 \mathrm{mg} / \mathrm{L}$ level (Table 1), with possible disruption of the negatively charged cell membrane [14]. Previous work using microalgae, Chlamydomonas reinhardtii, and yeast, Saccharomyces cerevisiae, has also confirmed the formation of a significant build-up of NPs on the cell surface for bare and cationic polyelectrolyte-coated $\mathrm{TiO}_{2} \mathrm{NPs}$ at pH 5.5 [14]. In contrast, titania was also detected on the outer surface of microtome-sectioned $D$. rerio embryos exposed to $500 \mathrm{mg} / \mathrm{L}$ anionic-coated $\mathrm{TiO}_{2}$ NPs/PSS in both dark and visible light conditions (Table 1). Regarding possible mechanisms to understand how such particle build up may occur, the negative charge of the cell membrane has been suggested to facilitate internalization, and affect the toxicity of positively charged coated NPs in other studies, such as gold NPs (AuNPs), which are more toxic than negatively and/or neutrally charged AuNPs $[35,36]$. In terms of additional coatings and nanohybrids, the toxicity of $\mathrm{TiO}_{2} \mathrm{NP}$ and $\mathrm{TiO}_{2}-\mathrm{MWCNT}$ nanohybrid has also been assessed with and without UV light exposure using zebrafish embryos, and neither presented acute toxicity [37]. The acute effects of $\mathrm{TiO}_{2} \mathrm{NPs}$ in zebrafish embryos thus depend on both the type of formulation and the illumination condition.

Three biological effects markers of sub-lethal impacts were examined. The expression of SOD 2 mRNA in pooled zebrafish embryos $(n=10)$ was affected by the type of $\mathrm{TiO}_{2} \mathrm{NPs}$, concentration, and condition (Table 2, Fig. 5) specifically indicating an oxidative stress response. This finding is consistent with those reported by Bar-llan et al. [30] whereby exposure to $10 \mu \mathrm{g} / \mathrm{L}-10 \mathrm{mg} / \mathrm{L} \mathrm{TiO}_{2} \mathrm{NPs}$, illuminated with a lamp, produced toxicity through cumulative reactive oxygen species. The expression levels of the hypoxia and membrane markers, HIF1 and Pxmp2, were not significantly impacted by any factor using the same exposure conditions. The SOD enzyme catalyses the conversion of the reactive superoxide ion $\left(\mathrm{O}_{2}^{-}\right)$to yield hydrogen peroxide $\left(\mathrm{H}_{2} \mathrm{O}_{2}\right)$ and oxygen molecule during oxidative oxygen processes [38]. Other markers of oxidative stress, increased catalase and glutathione $S$-transferase expression levels have also been reported in zebrafish embryos, exposed to $\mathrm{TiO}_{2} \mathrm{NPs}$ for $96 \mathrm{~h}$, under either visible light or a combination of visible and ultraviolet (UV) light [32]. Felix et al. [39] examined sublethal biological effects impacts of $0.1,1$ or $10 \mathrm{mg} / \mathrm{L}$ of uncoated $\mathrm{TiO}_{2} \mathrm{NPs}$, poly(acrylic acid)-coated $\mathrm{TiO}_{2} \mathrm{NPs}$, and the polymer coating alone, in the presence or absence of UV light, reporting that uncoated $\mathrm{TiO}_{2} \mathrm{NPs}$ produced hydroxyl radicals, delayed hatching, induced lipid peroxidation, increased catalase activity and total glutathione levels, and up-regulated glutathione peroxidase $1 a$ gene expression in the presence of UV light, while polymercoated $\mathrm{TiO}_{2} \mathrm{NP}$ increased thiobarbituric acid reactive substances production and total glutathione levels under simulated sunlight illumination. Further experiments are needed, with an increased number of embryos in each treatment group, and a shorter defined embryo stage (from 0 to $72 \mathrm{hpf}$ range), in order to reduce the variation of gene expression within treatment groups observed. 


\section{Conclusions}

In summary, $\mathrm{TiO}_{2} \mathrm{NP}$ size, surface charge, concentration and the presence/absence of light have been shown to determine their potential toxicity measured in this study as specific gene expressions. Polyelectrolytes coatings were used in formulations to enhance dispersion stability [40]. The polyelectrolyte multilayer films (PAH/PSS) provide a stable nanocomposite thin film that interacts with the NPs [41]. The nanotoxicty of polyelectrolytecoated $\mathrm{TiO}_{2} \mathrm{NPs}$ have been previously been studied in yeast and microalgae and the results showed that the toxicity of the coated $\mathrm{TiO}_{2} \mathrm{NPs}$ changes with their surface charge where cationic polyelectrolyte coating were more toxic than the anionic polyelectrolyte coating [14]. Here, we compare the toxicity of different $\mathrm{TiO}_{2} \mathrm{NPs}$ coatings on $D$. rerio embryos and find that $D$. rerio embryos remain viable after exposure to 500 and $1000 \mathrm{mg} / \mathrm{L}$ of $\mathrm{TiO}_{2} \mathrm{NPs}$ coated with anionic and cationic polyelectrolytes for $3 \mathrm{~h}$. Also, embryos exposed to $\mathrm{TiO}_{2} \mathrm{NPs}$ coated with cationic polyelectrolytes showed no Ti on the embryo using EDS while the higher dose of $1000 \mathrm{mg} / \mathrm{L}$ of the same coating start to show NPs residues. Importantly, the biological sub-lethal effects marker, SOD2 expression, showed significant changes related to all factors, indicative of oxidative stress. Similarly, HIF1 expression showed a significant difference in response to condition. This study focused on a relatively short-term exposure with concentrations that are not environmentally relevant. It would be interesting to understand how NPs at environmentally realistic exposure levels affect $D$. rerio over longer exposure periods, at defined embryo stages, and also several generations.

Acknowledgements This work was financially supported by the University of Jordan in funding to Zeinab Arabeyyat.

\section{Compliance with ethical standards}

Conflict of interest The authors report that there are no conflict of interest.

Open Access This article is licensed under a Creative Commons Attribution 4.0 International License, which permits use, sharing, adaptation, distribution and reproduction in any medium or format, as long as you give appropriate credit to the original author(s) and the source, provide a link to the Creative Commons licence, and indicate if changes were made. The images or other third party material in this article are included in the article's Creative Commons licence, unless indicated otherwise in a credit line to the material. If material is not included in the article's Creative Commons licence and your intended use is not permitted by statutory regulation or exceeds the permitted use, you will need to obtain permission directly from the copyright holder. To view a copy of this licence, visit http://creativecommons .org/licenses/by/4.0/.

\section{References}

1. Rollerova E, Tulinska J, Liskova A, Kuricova M, Kovriznych J, Mlynarcikova A, Kiss A, Scsukova S (2015) Titanium dioxide nanoparticles: some aspects of toxicity/focus on the development. Endocrine Regulations 49:97-112

2. Gelis C, Girard S, Mavon A, Delverdier M, Paillous N, Vicendo P (2003) Assessment of the skin photoprotective capacities of an organo-mineral broad-spectrum sunblock on two ex vivo skin models. Photodermatol Photoimmunol Photomed 19:242-253

3. Tsuji JS, Maynard AD, Howard PC, James JT, Lam C, Warheit DB, Santamaria $A B$ (2006) Reasearch strategies for safety evaluation of nanomaterials, part IV: risk assessment of nanoparticles. Toxicol Sci 89:42-50

4. Kaida T, Kobayashi K, Adachi M, Suzuki F (2004) Optical characteristics of titanium oxide interference film and the film laminated with oxides and their application for cosmetics. J Cosmet Sci 55:219-220

5. Wiesenthal A, Hunter L, Wang S, Wickliffe J, Wilkerson M (2011) Nanoparticles: small and mighty. Int J Dermatol 50:247-254

6. Chen J, Poon C-S (2009) Photocatalytic construction and building materials: from fundamentals to applications. Build Environ 44:1899-1906

7. Koivisto AJ, Lyyranen J, Auvinen A, Vanhala E, Hameri K, Tuomi T, Jokiniemi J (2012) Industrial worker exposure to airborne particles during the packing of pigment and nanoscale titanium dioxide. Inhal Toxicol 24:839-849

8. Ackroyd R, Kelty C, Brown N, Reed M (2001) The history of photodetection and photodynamic therapy. Photochem Photobiol 74:656-669

9. Cho M, Chung H, Choi W, Yoon J (2004) Linear correlation between inactivation of $E$. coli and $\mathrm{OH}$ radical concentration in $\mathrm{TiO}_{2}$ photocatalytic disinfection. Water Resour 38:1069-1077

10. Esterkin CR, Negro AC, Alfano OM, Cassano AE (2005) Air pollution remediation in a fixed bed photocatalytic reactor coated with $\mathrm{TiO}_{2}$. AIChE J 51:2298-2310

11. Choi $H$, Stathatos E, Dionysiou DD (2006) So-lgel preparation of mesoporous photocatalytic $\mathrm{TiO}_{2}$ films and $\mathrm{TiO}_{2} / \mathrm{Al}_{2} \mathrm{O}_{3}$ composite membranes for environmental applications. Appl Catal B 63:60-67

12. Uchino T, Tokunaga $\mathrm{H}$, Ando $\mathrm{M}$, Utsumi H (2002) Quantitative determination of $\mathrm{OH}$ radical generation and its cytotoxicity induced by $\mathrm{TiO}(2)$-UVA treatment. Toxicol In Vitro 16:629-635

13. Therapeutics Good Administration (TGA) (2013) Literature review on the safety of titanium dioxide and zinc oxide nanoparticles in sunscreens. TGA, Symonston, ACT

14. Al-Awady MJ, Greenway GM, Paunov VN (2015) Nanotoxicity of polyelectrolytefunctionalized titania nanoparticles towards microalgae and yeast: role of the particle concentration, size and surface charge. RSC Adv 5:37044-37059

15. Halbus AF, Horozov TS, Paunov VN (2019) Self-grafting copper oxide nanoparticles show a strong enhancement of their antialgal and anti-yeast action. Nanoscale Adv 1:2323-2336

16. Barker PJ, Branch A (2008) The interaction of modern sunscreen formulations with surface coatings. Prog Org Coat 62:313-320

17. Dodd NJF, Jha AN (2011) Photoexcitation of aqueous suspensions of titanium dioxide nanoparticles: an electron spin resonance spin trapping study of potentially oxidative reactions. Photochem Photobiol 87:632-640

18. Xiong D, Fang T, Yu L, Sima X, Zhu W (2011) Effects of nano-scale $\mathrm{TiO} 2, \mathrm{ZnO}$ and their bulk counterparts on zebrafish: acute toxicity, oxidative stress and oxidative damage. Sci Total Environ 409:1444-1452 
19. Federici G, Shaw BJ, Handy RD (2007) Toxicity of titanium dioxide nanoparticles to rainbow trout (Oncorhynchus mykiss): gill injury, oxidative stress, and other physiological effects. Aquat Toxicol 84:415-430

20. Petersen EJ, Reipa V, Watson SS, Stanley DL, Rabb SA, Nelson BC (2014) DNA damaging potential of photoactivated P25 titanium dioxide nanoparticles. Chem Res Toxicol 27:1877-1884

21. Wu J, Liu W, Xue C, Zhou S, Lan F, Bi L, Xu H, Yang X, Zeng F-D (2009) Toxicity and penetration of $\mathrm{TiO} 2$ nanoparticles in hairless mice and porcine skin after subchronic dermal exposure. Toxicol Lett 191:1-8

22. Okuda-Shimazaki J, Takaku S, Kanehira K, Sonezaki S, Taniguchi A (2010) Effects of titanium dioxide nanoparticle aggregate size on gene expression. Int J Mol Sci 11:2383-2392

23. Mills A, Le Hunte S (1997) An overview of semiconductor photocatalysis. J Photochem Photobiol, A 108:1-35

24. Carlotti ME, Ugazio E, Sapino S, Fenoglio I, Greco G, Fubini B (2009) Role of particle coating in controlling skin damage photoinduced by titania nanoparticles. Free Radical Res 43:312-322

25. Ma H, Brennan A, Diamond SA (2012) Photoxicity of $\mathrm{TiO}_{2}$ nanoparticles under solar radiation to two aquatic species: Daphnia magna and Japanese medaka. Environ Toxicol Chem 31:1621-1629

26. Adams LK, Lyon DY, Alvarez PJJ (2006) Comparative eco-toxicity of nanoscale $\mathrm{TiO}_{2}, \mathrm{SiO}_{2}$, and $\mathrm{ZnO}$ water suspensions. Water Res 40:3527-3532

27. Oparka KJ, Read ND (1994) The use of fluorescent probes for studies on living plant cells. In: Harris N, Oparka KJ (eds) Plant cell biology' A Practical Approach, pp 27-50

28. Livak KJ, Schmittgen TD (2001) Analysis of relative gene expression data using real-time quantitative PCR and the $2_{\mathrm{T}}^{-\Delta \Delta C}$ method. Methods 25:402-408

29. Kovriznych JA, Sotnikova R, Zeljenkova D, Rollerrova E, Szabova E, Wimmerova S (2013) Acute toxicity of 31 different nanoparticles to zebrafish (Danio rerio) tested in adulthood and in early life stages-comparative study. Interdiscip Toxicol 6:67-73

30. Bar-llan O, Chuang CC, Schwahn DJ, Yang S, Joshi S, Pedersen JA, Hamers RJ, Peterson RE, Heideman W (2013) $\mathrm{TiO}_{2}$ Nanoparticle exposure and illumination during zebrafish development: mortality at parts per billion concentrations. Environ Sci Technol 47:4726-4733

31. $\mathrm{Ma} \mathrm{H}$, Diamond SA (2013) Phototoxicity of $\mathrm{TiO}_{2}$ nanoparticles to zebrafish (Danio rerio) is dependent on life stage. Environ Toxicol Chem 32:2139-2143. https://doi.org/10.1002/etc.2298
32. Clemente Z, Castro VLSS, Moura MAM, Jonsson CM, Fraceto LF (2014) Toxicity assessment of TiO2 nanoparticles in zebrafish embryos under different exposure conditions. Aquat Toxicol 147:129-139

33. Sun CK, Chu SW, Chen SY, Tsai TH, Liu TM, Lin CY, Tsai HJ (2004) Higher harmonic generation microscopy for developmental biology. J Struct Biol 147:19-30

34. Cunningham S, Brennan-Fournet ME, Ledwith D, Byrnes L, Joshi $L$ (2013) Effect of nanoparticle stabilization and physicochemical properties on exposure outcome: acute toxicity of silver nanoparticle preparations in zebrafish (Danio rerio). Environ Sci Technol 47:3883-3892

35. Goodman CM, McCusker CD, Yilmaz T, Rotello VM (2004) Toxicity of gold nanoparticles functionalized with cationic and anionic side chains. Bioconjug Chem 15:897-900

36. Lin J, Zhang H, Chen Z, Zheng Y (2010) Penetration of lipid membranes by gold nanoparticles: insights into cellular uptake, cytotoxicity, and their relationship. ACS Nano 4:5421-5429

37. Silva GHD, Clemente Z, Khan LU, Coa F, Neto LLR, Carvalho HWPVL, Martinez DST, Monteiro RTR (2018) Toxicity assessment of $\mathrm{TiO}_{2}-$ MWCNT nanohybrid material with enhanced photocatalytic activity on Danio rerio (Zebrafish) embryos. Ecotoxicol Environ Saf 165:136-143. https://doi.org/10.1016/j.ecoen v.2018.08.093

38. Velkova-Jordanoska L, Kostoski G, Jordanoska B (2008) Antioxidative enzymes in fish as biochemical indicators of aquatic pollution. Bulgarian J Agric Sci 14:235-237

39. Felix LC, Folkerts EJ, Yuhe He Y, Goss GG (2017) Poly(acrylic acid)coated titanium dioxide nanoparticle and ultraviolet light coexposure has minimal effect on developing zebrafish (Danio rerio). Environ Sci Nano 4:658-669. https://doi.org/10.1039/ c6en00436a

40. Batley GE, Kirby JK, Mclaughlin MJ (2013) Fate and risks of nanomaterials in aquatic and terrestrial environments. Acc Chem Res 46:854-862

41. Cho J, Caruso F (2005) Investigation of the interactions between ligand-stabilized gold nanoparticles and polyelectrolyte multilayer films. Chem Mater 17:4547-4553

Publisher's Note Springer Nature remains neutral with regard to jurisdictional claims in published maps and institutional affiliations. 